\title{
EMPATHETIC LEADERSHIP, JOB SATISFACTION AND INTENTION TO LEAVE AMONG MILLENNIALS IN A START-UP INDUSTRY: NEEDS' SATISFACTION AS A MEDIATING VARIABLE
}

\author{
Muhammad Cesare Wicaksana Negoro ${ }^{1}$ and Amin Wibowo ${ }^{1} *$ \\ Department of Management, Faculty of Economics and Business, Universitas Gadjah Mada, \\ Yogyakarta, 55281, Indonesia
}

\begin{tabular}{|c|c|}
\hline ABSTRACT & ARTICLE INFO \\
\hline $\begin{array}{l}\text { Introduction/Main Objectives: The purpose of this research is to examine } \\
\text { the relationship between empathetic leadership and employees' job } \\
\text { satisfaction and the intention to leave with needs' satisfaction as a mediating } \\
\text { variable among millennials in a start-up business. The number of millennials } \\
\text { will only continue to grow, and by } 2025 \text { it is expected that } 75 \% \text { of the global } \\
\text { workforce will be millennials. In particular, empathetic leadership will be } \\
\text { required to manage and control this generation if the organizations they } \\
\text { choose to work for are to be successful, as this generation's members have } \\
\text { different characteristics compared to those of the older generations. } \\
\text { Design/methodology/approach: Following a cross-sectional research } \\
\text { design, this research collected data from } 137 \text { millennial employees of start- } \\
\text { up companies in Indonesia. A structural equation modeling technique was } \\
\text { used for the data's analysis. Findings: The results reveal that empathetic } \\
\text { leadership has a direct and positive relationship with employees' job } \\
\text { satisfaction and has a direct and negative relationship with the intention to } \\
\text { leave. Needs' satisfaction partially mediates these relationships. Originality: } \\
\text { This study makes a novel contribution to the existing literature by first } \\
\text { providing empirical evidence that among the three dimensions of needs' } \\
\text { satisfaction only the relatedness dimension passed the measurement test in } \\
\text { the structural equation modeling. Second, empathetic leadership is proven to } \\
\text { increase job satisfaction and reduce the intention to leave among millennials, } \\
\text { considering their unique characteristics. Research limitations/implications: } \\
\text { The research was conducted during COVID-19 pandemic. Circumstances } \\
\text { related to that pandemic might influence the result of this study. It is, } \\
\text { therefore suggested to conduct the study again under normal circumstances. } \\
\text { Policy and Practical implications: The findings of this study suggest } \\
\text { managers should develop an empathetic leadership style in order to better } \\
\text { manage the millennials. Leaders can be nurtured, but disciplined efforts have } \\
\text { to be invested in their creation. }\end{array}$ & $\begin{array}{l}\text { Article information: } \\
\text { Received } 7 \text { January } 2021 . \\
\text { Received in revised form } \\
15 \text { March 2021. Received } \\
\text { in revised form } 26 \text { March } \\
\text { 2021. Accepted } 29 \text { March } \\
2021 \\
\text { Keywords: } \\
\text { empathetic leadership, } \\
\text { needs' satisfaction, job } \\
\text { satisfaction, intention to } \\
\text { leave, millennials, start-up } \\
\text { industry } \\
\text { JEL Code: } \\
\text { M120 }\end{array}$ \\
\hline
\end{tabular}

\footnotetext{
* Corresponding Author. Researcher at Department Management, Faculty of Economics and Business, Universitas Gadjah Mada, Yogyakarta, Indonesia 55281.

Email address: cesarenegoro@gmail.com aminwibowo@ugm.ac.id (corresponding author)
} 


\section{INTRODUCTION}

Leadership is a long-standing research topic, and will continue to be an important issue depending on the context in which leadership is exercised, which in this case is leadership of the millennial generation who are working in a new type of business - a start-up. How would you lead the members of this generation who are stereotyped as being lazy, having no respect for authority, bad work habits, and unrealistic expectations? (Ferri-Reed, 2014). Leading the millennials, who were born from 1984 to 1999 , is a major challenge for most leaders, and most leaders cannot avoid it as the number of millennials in employment will only continue to grow; by 2030 it is expected that $75 \%$ of the global workforce will be millennials (Millennials in the workplace, 2017). As is the nature of management, managers and their work are changing (Martin, 2005), as with the case of millennials in start-up industry, a leadership style that brings out the best performance from millennials is needed. Among other leadership styles, this study focused on empathetic leadership for several reasons. First, empathic leadership is characterized by focusing on understanding the emotional situation of others, and showing a willingness to care about them and take action to serve them (Kock et al., 2018), compared to transactional leadership styles that focus on specific tasks and use rewards and punishments to motivate followers, or transformational leadership that encourages, inspires and motivates employees (Bass, 1990). Second, empathetic leadership is also relevant because it presents other people's experiences (i.e. the experiences of followers) and provides genuine understanding and support through changes and difficult times, regardless of the followers' performance. Third, empathic leadership can be considered a newly developed construct (Kock et al., 2018) and hence, it has not been widely studied in terms of its organizational outcomes and contextual relevance. This study will examine the relationship between empathic leadership with job satisfaction and turnover intentions, and determine the mediating role of needs' satisfaction. Thus, the theoretical contribution is expected to be significant.

The millennials are known for having the following characteristics: (a) They see themselves as a human being first before being an employee (Bolland \& Lopes, 2014; Wong et al., 2008). (b) They are known as the "job hopping generation" because they change jobs more frequently than do those belonging to the older generations (Gallup, 2016). (c) They are much more technologically savvy, and they adapt better to technological changes compared to their predecessors since they have been accustomed to the Internet of things from an early age (PWC, 2011). (d) They feel a greater need to be appreciated in their workplace. These characteristics create an emotional and peopleoriented work environment, as opposed to the mechanical 9 to 5 traditional workplace culture (Hughes, 2015), which demands a leadership style that fulfills the well-being of millennials, such as giving them satisfying work to perform, as well as making them feel comfortable working for the organization, so they have less intention to leave. In addition, apart from salary, millennials are considered to place emphasis on having a meaningful job (Murphy, 2018), creative freedom, and the opportunity to develop themselves (Utomo, 2019), as well as a feeling of connection with their co-workers (Landrum, 2018) in choosing a job. With regard to this, Deci et al.,(2001) highlighted the importance of needs' satisfaction when discussing the wellbeing of employees in the work setting. These needs are similar to the essential nutriments needed for people to thrive, especially for the millennials who consider the work-life balance 
as an important thing in their life (Bolland \& Lopes, 2014).

Among many leadership styles, this study proposes that empathetic leadership is needed when dealing with millennials. Empathetic leadership is defined as a leadership style that focuses on understanding other people's emotional situations, and showing a willingness to care about them and take actions to cater to them (Kock et al., 2018). Since its focus is on developing an emotional relationship, showing and exercising empathy will be part of a more person-focused leadership style. Empathy is the ability to experience and relate to the thoughts, emotions, or experience of others. The style proposes that people would be better leaders when they have an understanding of their followers' emotional states, so they can express this understanding, and support their followers' handling of these emotions. It is important for leaders to bond and create personal relationships with their employees, as there are several benefits to this. First, the employees in general are more satisfied and emotionally less exhausted (Maslach \& Leiter, 2016). Second, a good relationship with their supervisors also leads to the employees having a better sense of their psychological-needs satisfaction (Deci et al., 2001), which will then lead to a greater work-life balance environment, and employees feeling satisfied with their jobs (Reb et al., 2012), which reduces their intention to quit the organizations they work for (Gallup, 2016). Although there was a study about millennials in a similar context (see Negoro, 2020), that study left the intention to leave uninvestigated. As one of the generation that do not feel they have to have close ties to their work (Gallup, 2016), it is important to investigate how the empathetic leadership approach helps this generation settle in their jobs, reducing the cost for the organization to replace them if they leave for another job. Such an understanding is one thing this study would like to contribute.

Contextually, this study is conducted on millennials in start-up businesses. Although there have been studies on millennials (Smith \& Nichols, 2015; Kaifi et al., 2012; Chou, 2012, among many others), the leadership and followership styles exhibited by millennials at work has been largely neglected. Leaders must learn more about their employees' job satisfaction and intention to leave as new generations merge within their organization. Thus, the major purpose of this study is to develop an understanding of the relationship between the empathetic leadership style and job satisfaction and intention to leave, while considering needs' satisfaction as a mediating variable.

As millennials are way more technologically knowledgeable, working for a start-up company where technology is heavily utilized to deliver products or services is a reasonable choice. Working for a start-up company is also meaningful for millennials, as many start-up companies utilize technology to solve the problems that society is facing (e.g. the problem of environmental sustainability) (HansonRasmussen \& Lauver, 2018). Examples of these include online shopping, e-ticketing, online transportation and e-commerce. In addition, many start-up companies have been implementing flexible working schedules (ChopraMcGowan, 2019), dress as you like policies (Williams, 2017), and a people-oriented culture (Hughes, 2015) which all match with the characteristics of the millennials. Having discussed the conceptual and contextual above, first, this study acknowledges that leading the millennials in start-up companies merits investigation as the number of members of this generation entering the workforce is growing, and the become the dominant workforce in many organizations. Failing to lead this generation can 
contribute to costs associated with maintaining the workforce. Second, as this generation is less attached to their work, a leader needs to understand how to lead this generation, so that organizations reap the benefits of having a good quality workforce. Third, focusing on understanding the emotional situation of others, and showing a willingness to care about them and take action, may result in maintaining the satisfaction of millennials with the organization and reducing their intention to quit. Based on the above arguments, this study tries to answer the following questions. Firstly, whether there is a relationship between empathetic leadership and job satisfaction. Secondly, whether there is a link between empathetic leadership and the turnover intention. Thirdly, whether there is a mediating role for needs' satisfaction on the relationship of the above variables. In accordance with the above research questions, this study developed and tested a model that relates empathetic leadership with job satisfaction, and the intention to leave, and puts needs' satisfaction as the mediating variable.

In the next section, the literature review, in regard to the variables of this study, namely empathetic leadership, needs' satisfaction, job satisfaction, and intention to leave are further discussed in detail. The discussion highlights the definition and the development of the concept in the literature. Following the above discussions, the proposed hypotheses development is examined in detail.

\section{LITERATURE REVIEW}

\section{Empathetic Leadership}

Kock et al., (2018) defined empathetic leadership as a leadership style that focuses on understanding its followers' emotional situations, and the willingness to care about them and take actions to cater for them. Empathy is defined as the ability to recognize and understand the feelings of others (Stevenson, 2010). Even in the workplace people need support and understanding, or empathy (Edmondson \& Lei, 2014). Psychological and leadership studies show that empathy provides a foundation for the behavior of many people (Ilies et al., 2006). Very often leaders utilize empathy in the workplace to create positive and comfortable conditions for their followers (Owens \& Hekman, 2016). Empathy is used by humans to survive, because with empathy, one can understand that whoever shows empathy can be trusted, and can be invited to work with others (Kock et al., 2018). However, few studies have focused on understanding other people's emotional situations and shown a willingness to care and take actions to cater to them (Kock et al., 2018). Dealing with a generation that see themselves as human beings before being employees, leaders with an understanding of the emotional aspects and a willingness to care are needed if these people are going to be useful in the workplace. The leadership style that focuses on understanding other people's emotional situations, and shows a willingness to care about them and take actions to cater to them (Kock et al., 2018) is termed empathetic leadership. Thus, with empathy in place, there can be a good relationship between one person and another.

\section{Need Satisfaction}

The self-determination theory (Ryan \& Deci, 2002) claimed that humans are motivated and show well-being when they have their psychological needs satisfied. There are three needs that are generally owned by humans that require satisfying: autonomy, competence, and relatedness. Autonomy is a person's need to feel that his/her behavior and the outcome of his/her work are self-determined or self-caused, and not because they are controlled or influenced by outside forces (Ryan \& Deci, 2000). 
Competence is the need for a person to feel capable and effective in carrying out tasks or jobs, with different levels of difficulty, which are assigned to them (Ryan \& Deci, 2002), while relatedness is the need for people to feel connected to, supported by, or cared for by others, including at their workplace (Ryan \& Deci, 2002). The discussions related to need have been well documented. McClelland and Burnham (1976) defined needs as referring to a person's conscious wants, desires, or emotions. As an alternative view, Ryan et al., (1996) defined needs in terms of the nutriments that are essential for individuals to survive and grow. This view of needs assumes that needs are innate rather than learned. This study followed the latter definition based on the following reasons: first, everyone is assumed to have innate needs regardless of their reported desire for the outcomes they expect, and second, assessing needs allows this study to undertake an empirical exploration, and not just make assumptions.

\section{Job Satisfaction}

Locke (1976) p. 1304) defined job satisfaction as "a pleasurable or positive emotional state resulting from the appraisal of one's job or work experiences." Whether someone is satisfied, or not, at work is a result of the various attitudes that a person has toward work, and toward factors related to life in general (Gilmer, 1974). Job satisfaction reflects the sense of achievement and success of an employee. Achievement and success both depend on job satisfaction and motivation (Purnomo et al., 2020; Qodriah et al., 2019). By having job satisfaction, workers work happily, do their jobs well, and feel valued for their efforts. Someone who is satisfied with his/her work tends to work happily and enthusiastically (Zhu, 2012). In other words, job satisfaction refers to the positive emotion that comes as a result of positive experiences in the workplace, and people will reflect the positive behavior from their job in their life in general. Backing this assertion, Zhu (2013) who reviewed job satisfaction in detail, proposed that as an attitude job satisfaction consisted of three things, namely cognitive components, affective components, and behavioral components. In addition, Locke (1976) offered the definition of job satisfaction as a kind of pleasant or positive affective state, which grows as part of the process of evaluating an individual's work experiences.

\section{Intention to Leave}

Firth et al., (2004) stated that employees' intention to leave describes employees who are considering and thinking about leaving where they currently work. An intention is an indication of an individual's readiness to perform a given behavior (Ajzen, 1991). Over time, the pressure to perform and uncertainty that results from the working enviroment can be difficult to accept for many employees, meaning some workers are eager to leave their jobs or organizations (Cardador et al., 2011). When an employee leaves, the investment made by the company in the employee, in terms of education, training and development is lost. A high turnover of employees may also cause the morale of the remaining ones to decline (Ertas, 2015). A low turnover intention however, may provide benefits to the organization, such as it saves an organization a great deal in human resources expenses. In more detail, the costs of exit interviews with outgoing employees, the costs to hire temporary help before a new employee can be found, the costs to attract and retain new employees, and the costs to train new employees can all be avoided with low turnover. The turnover intention has always been an important issue faced by organizations, regardless of their location, size, and the nature 
of their business. If not solved, the cost expenditure associated with employee turnover will increase (Ali, 2009; Long \&Thean, 2011).

\section{HYPOTHESES DEVELOPMENT}

\section{The Direct Relationship of Empathetic Leadership to Job Satisfaction}

Basically, leadership is based on relationships (Bennis, 2007). For example, the leadermember exchange (LMX) theory explains how leaders and followers build bonds (Lloyd et al., 2015), and in many cases this happens beyond the requirements of the workplace. Well-being and extra-role behavior might emerge as a consequence of a good relationship between leaders and followers (Geertshuis et al., 2015). Empathy, in this case, provides the possibility of explaining why followers experience job satisfaction. Empathetic leaders show their followers that they are to be trusted, they encourage the efforts of the followers, they show concern about the job satisfaction of the followers, and they also support their professional development (Mayfield \& Mayfield, 2015). In an office setting, empathy has allowed leaders to give signals to their followers that they can trust them and they can create positive feelings toward the workplace by establishing personal and emotional connections (Madlock, 2008). The use of empathy in the workplace creates a positive state of mind in the followers (Gilet et al., 2013; Owens \& Hekman, 2016), such as satisfaction with their job and that they like working in that place. Accordingly, the following hypothesis was developed:

H1: Empathetic leadership has a positive effect on employees' job satisfaction

\section{The Direct Relationship of Empathetic Leadership with the Intention to Leave}

Empathetic leaders focus on understanding the emotional situation of their followers, they are willing to care about them, they communicate well with them, and take the actions needed to treat followers in the best way possible (Kock et al., 2018). In companies where the environment is dynamic and has great levels of uncertainty, as is the case in start-up firms, having leaders like these make the employees feel more comfortable at work, which reduces their desire to quit. The Work Institute (Mahan et al., 2019) projected that the millennial employee turnover rate would increase over time, and by 2023, voluntary employee turnover was expected to rise to nearly $30 \%$, so managers must try to seriously reduce the intention to leave among their employees, and in this study empathetic leadership is believed to reduce that intention.

Based on the above, the following hypothesis was formulated:

H2: Empathetic leadership has a negative effect on employees' intention to leave

\section{Needs' Satisfaction as a Mediator between Empathetic Leadership and Job Satisfaction}

The needs' satisfaction of employees is hypothesized as a mediator in the relationship between empathetic leadership and job satisfaction, as many studies state that when leaders are emotionally supportive, followers feel connected to, supported by, or cared for by their leaders in the workplace (Baumeister \& Leary, 1995; Ryan \& Deci, 2002). As a result, the employees tend to be satisfied with their jobs (Bono et al., 2007; Chiesa \& Serretti, 2011). Similarly, when there is support and motivation from a supervisor, the feeling of being capable and effective at doing the tasks or job, and the feeling that his or her behavior and the outcome of their work are selfdetermined, or self-caused, will emerge (Ryan and Deci, 2002), and later they will feel satisfied with their job (Reb et al., 2012). Based on the above arguments, the following hypothesis was 
proposed:

H3: Needs' satisfaction mediates the positive effect of empathetic leadership for employees' job satisfaction.

\section{Needs' Satisfaction as a Mediator between Empathetic Leadership and the Intention to Leave}

It is known that the desire to leave is influenced by environmental factors and individual factors (Cardador et al., 2011). Each individual has different psychological needs that require satisfying, which functions as a mediator when there is a relationship between empathetic leadership and the desire to leave. With the empathetic leadership functions displayed by supervisors, this makes employees feel they are getting the attention, encouragement, and motivation they want (Baumeister \& Leary, 1995; Ryan \& Deci, 2002), which further reduces their desire to leave their job. With empathetic leadership, employees feel they have help to deal with challenging and stressful situations (Kock et al., 2018), and feel capable of doing their tasks (Ryan \& Deci, 2002). In turn, these psychological needs for satisfaction mediate the employees' desire to quit their work.

H4: Needs' satisfaction mediates the negative effect of empathetic leadership for employees' intention to leave.

\section{METHOD}

\section{Sample and Procedure}

The object was the millennial generation, meaning those who were born between 1984 and 1999, so they were 21 to 36 years old in 2020. Predetermined criteria were applied; they should be active employees of a start-up company, which operates in Indonesia. Nonprobability sampling with purposive samples (Sekaran \& Bougie, 2010) was applied. Researchers distributed descriptive information as well as a link that directed the respondents to a questionnaire that was arranged by the researcher. The online questionnaire was distributed via social media platforms such as LINE, WhatsApp and also LinkedIn by one of the researchers. From the responses received, 137 final responses were processed for the analysis. Sixty-nine respondents were male, and 67 were female, the eldest were born in 1984, and the youngest were born in 1999. All the respondents were working for start-up companies.

A quantitative research approach was applied. Three stages were proposed. First, the confirmatory factor analysis (CFA), used to determine the level of representation between the variable and the questionnaire items was applied, which resulted in the construct's reliability and variance extracted. Second, the goodness of fit of the measurement was applied to measure the construct's reliability and validity. Third, once the measurement part proved satisfactory, the third stage of the structural relationship was executed, which resulted in the relationship among the constructs of the study being exposed.

\section{Measures}

All measurements of the variables used in this study were adopted from previous research, and already had high measurement validity. Empathetic leadership (Kock et al., 2018) is a relatively new construct, and has rarely been investigated in relation to millennials. Job satisfaction and the intention to leave are important variables in managing a workforce, especially among millennials as they are less attached to their work. Lastly, the need for satisfaction, as a nutriment that is essential for an individual to survive and grow, is considered important when leading millennials. A 7-point Likert-type scale was applied for all the 
variables, consisting of strongly agree (SA), agree (A), somewhat agree (SWA), neutral (N), somewhat disagree (SWD), disagree (D), and strongly disagree (SD).

\subsection{Empathetic Leadership}

Empathetic leadership refers to the leadership model that emphasizes the leader's level of understanding and support for the followers' emotional states (Kock et al., 2018). The researcher utilized the empathetic part of the motivating language scale (Mayfield \& Mayfield, 2015) that consisted of five questions with a 7-point Likert-type scale. Examples of the questions included "My supervisor gives me praise for my good work." "My supervisor shows me encouragement for my work efforts."

\subsection{Need for Satisfaction}

The needs' satisfaction of employees is defined in the self-determination theory as innate, psychological, and essential for human wellbeing. There are three basic psychological needs that all humans have in common: autonomy, competence, and relatedness. The researcher utilized Deci \& Ryan's measures of the need for satisfaction at work from 2001, which divided the statements about needs' satisfaction into three sections: seven statements about autonomy, six statements about competence, and eight statements about relatedness. Examples of these statements included "I really like the people I interact with," and "People in my life care about me."

\subsection{Job Satisfaction}

Job satisfaction refers to the pleasurable or positive emotional state resulting from the appraisal of one's job or job experiences (Locke, 1976). The researcher utilized the job satisfaction measures of Cammann et al., (1983).
Examples of these statements included "All in all I am satisfied with my job," and "In general, I don’t like my job."

\subsection{Intention to Leave}

Intention to leave describes employees who are considering or thinking about leaving their work. The intention to leave was measured using a scale developed by Kelloway, Gottlieb and Barham, (1999). Sample items included "I am thinking about leaving this organization," and "I intend to ask people about new job."

\section{RESULTS}

\section{Correlations and Confirmatory Factor Analysis}

Table 1 presents the correlations between all the variables utilized in this study. A correlation is a statistical measure that expresses the extent to which two variables are linearly related (meaning they change together at a constant rate). The $p$-value represents the probability that the correlation between $\mathrm{x}$ and $\mathrm{y}$ in the sample data occurs by chance. A $p$-value of 0.05 means that there is only a $5 \%$ chance that the results from a sample occurred due to chance, while a $p$ value of 0.01 means that there is only a $1 \%$ chance. So lower $p$-values are good. As shown in that table, the correlations between empathetic leadership and the need for satisfaction ( $r=$ $0.569, p=0.01)$ and all the dependent variables, job satisfaction $(r=0.625, p=0.01)$, and intention to leave $(r=-0.490, p=0.01)$ were in accordance with the theoretical claim. The construct of the need for satisfaction was related but distinct to job satisfaction $(r=0.592, p=$ $0.01)$, and the intention to leave $(r=-0.503, p=$ $0.01)$. Similar evidence was also observed between job satisfaction and intention to leave $(r$ $=0.506, p=0.01$ ). 
Table 1. Descriptive Statistics and Correlations

\begin{tabular}{lccccccc}
\hline \multicolumn{1}{c}{ Construct } & Mean & SD & N & 1 & 2 & 3 & 4 \\
\hline Empathetic Leadership & 6.115 & 0.755 & 137 & & & & \\
Need for Satisfaction & 5.804 & 0.639 & 137 & $0.569^{* *}$ & & & \\
Job Satisfaction & 6.093 & 0.928 & 137 & $0.624^{* *}$ & $0.592^{* *}$ & & \\
Intention to Leave & 2.695 & 1.405 & 137 & $-0.490^{* *}$ & $-0.503^{* *}$ & $-0.506^{* *}$ & \\
\hline
\end{tabular}
** $p<0.01$

All the above evidence supports the statement that the high correlations between personal variables are the result of conceptual relationships and not measurement problems. However, to strengthen this argument, a confirmatory factor analysis is also important, to clarify the nature of the relationship between the variables (Table 2).

Table 2. Confirmatory Factor Analysis

\begin{tabular}{lcc}
\hline \multicolumn{1}{c}{ Construct } & $\begin{array}{c}\text { Construct } \\
\text { Reliability }\end{array}$ & $\begin{array}{c}\text { Variance } \\
\text { Extracted }\end{array}$ \\
\hline Empathetic Leadership & 0.909 & 0.671 \\
Need for Satisfaction & 0.867 & 0.568 \\
Job Satisfaction & 0.930 & 0.816 \\
Intention to Leave & 0.933 & 0.780 \\
\hline
\end{tabular}

Table 2 shows the result of the confirmatory factor analysis performed on all the variables of the study. When interpreting, the instrument's construct validity was applied. This is the extent to which the measure "behaves" in a way consistent with the theoretical hypotheses and represents how well the scores on the instrument are indicative of the theoretical construct. In assessing the reliability of multiple measures for an individual construct, the internal consistency measure developed by Fornell and Larcker (1981) was applied. Compared to Cronbach's alpha, this measure is believed to be superior since it uses the item loadings obtained within the causal model, it is not influenced by the number of indicators within the construct, and it is more general (Barclay et al., 1995; Hulland, 1999). A commonly used threshold value for acceptable reliability is 0.50 , which roughly corresponds to a standardized loading of 0.70 (Hair et al., 1998). Another measure of construct reliability is the variance extracted estimate. This reflects the overall amount of variance in the indicators accounted for by the latent construct (Fornell \& Larcker, 1981). Higher variance extracted values occur when the indicators are truly representative of the latent construct. Guidelines suggest that the variance extracted value should exceed 0.50 for the construct (Hair et al., 1998). Table 2 indicates that all the constructs had good construct reliability $(\geq 0.50)$, and variance extracted estimates $(\geq 0.50)$, confirming that the scale applied in this study differed and measured different constructs.

Table 3 indicates the results of the goodnessof-fit indices. It shows that the value of $X^{2}$ was above the 0.05 benchmark $(=0.074)$; RMSEA was below the 0.08 cut-off point $(=0.029)$; NFI, CFI, and GFI showed very good values $(=0.957$, 0.953 , and 0.903 respectively). AGFI was good $(=0.867)$. Overall the goodness-of-fit indices were satisfactory.

Table 3. Goodness-of-Fit Indices of Measurement Part

\begin{tabular}{lccc}
\hline Fit Indices & Result & Benchmark & Conclusion \\
\hline Probability of $X^{2}$ & 0.074 & $\geq 0.05$ & Good \\
RMSEA & 0.029 & $\leq 0.08$ & Good \\
NFI & 0.957 & $\geq 0.9$ & Good \\
CFI & 0.993 & $\geq 0.90$ & Good \\
GFI & 0.903 & $\geq 0.9$ & Good \\
AGFI & 0.867 & $0.8 \leq A G F I<0.9$ & Good \\
\hline
\end{tabular}


Table 2, along with Table 3, supports our argument that the relationship of the observed variables and their underlying constructs fulfill the measurement threshold for the structural equation modeling that was applied in this research. However, as some items of needs' satisfaction were felt in the measurement phase, then it is worth discussing them in the contribution and theoretical implication section in detail.

\section{Research Model and Coefficient of Structural Path}

The structural part permits the relationship between constructs to be examined. The result is shown in Figure 1.

Empathetic leadership predicted the employees' psychological needs' satisfaction ( $\beta$ $=0.580, \rho<0.001)$. Furthermore, the needs' satisfaction was positively associated with the dependent variable job satisfaction $(\beta=0.306, \rho$ $<0.001$ ), and was negatively associated with the dependent variable intention to leave $(\beta=$ $0.407, \rho<0.001)$. Finally, the results indicated that the psychological needs' satisfaction partly mediated the relation of empathetic leadership with job satisfaction $(\beta=0.532, \rho<0.001)$, and intention to leave $(\beta=0.360, \rho<0.001)$.

Summing up the research model, the goodness-of-fit indices of the structural relationship are presented in Table 4 . The $p$ value of $X^{2}$ was above the 0.05 benchmark $(=0.057)$; RMSEA was below the 0.08 cut-off point ( $=0.03$ ); NFI, CFI, and GFI showed very good values $(=0.957,0.992$, and 0.901 respectively). AGFI was also good $(=0.864)$. The RMSEA is an absolute fit index, in that it assesses how far a hypothesized model is from a perfect model. NFI is an incremental measure of the goodness of fit for a statistical model, which is not affected by the number of parameters/ variables in the model. CFI analyzes the model's fit by examining the discrepancies between the data and the hypothesized model, while adjusting for the issues of sample size inherent in the chi-squared test of the model's fit, and the normed fit index. GFI is a measure of the fit between the hypothesized model and the observed covariance matrix. The adjusted goodness of fit index (AGFI) corrects the GFI, which is affected by the number of indicators of each latent variable. Overall the goodness-of-fit indices were satisfactory.

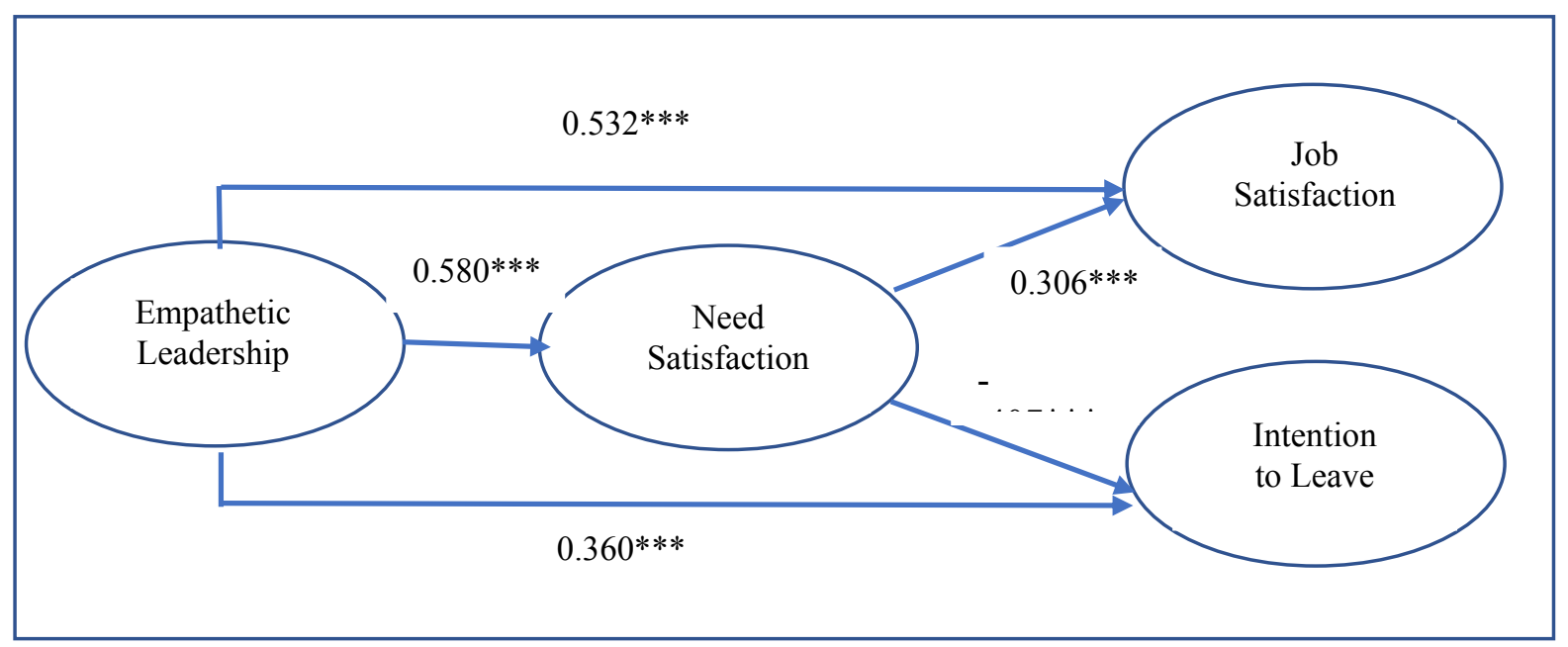

Note: $* * * p<0.01$

Figure 1: The Model of the Relationship of Empathetic Leadership, Needs' Satisfaction, Job Satisfaction and Intention to Leave 
Table 4. Goodness-Fit Indices of Structural Part

\begin{tabular}{lccc}
\hline \multicolumn{1}{c}{ Fit Indices } & Result & Benchmark & Conclusion \\
\hline Probability of $X^{2}$ & 0.057 & $\geq 0.05$ & Good \\
RMSEA & 0.03 & $\leq 0.08$ & Good \\
NFI & 0.957 & $\geq 0.9$ & Good \\
CFI & 0.992 & $\geq 0.90$ & Good \\
GFI & 0.901 & $\geq 0.9$ & Good \\
AGFI & 0.864 & $0.8 \leq A G F I<0.9$ & Good \\
\hline
\end{tabular}

\section{Hypotheses Testing and Discussion}

Having analyzed the data, the study expected the following. First, all the data satisfied the requirements of the descriptive statistics, the measurement part in the form of reliability and validity, and the structural part of the analysis in the form of the relationship among the variables. Second, the study expected to generalize the findings from the available data. The first expectation has been fulfilled as all the data passed the benchmark applied by this study. However, the second expectation was hardly fulfilled as the study was conducted during the COVID-19 pandemic, and with millennials as the respondents, the generalization of the findings is limited. The inability to generalize the findings is also a limitation of the study, thus a cautious interpretation of the result is suggested. The result of the analysis shows that Hypothesis 1 is supported. Hypothesis 1 argued that empathetic leadership is positively related to job satisfaction. This result corresponds to the findings in the previously conducted research (Kock, et al., 2018) which argued that high levels of empathetic leadership are indeed related to greater job satisfaction for employees. The positive relationship between the two variables in this study is in line with the relational leadership theory and the leadermember theory, in showing the importance of the relationship between leaders and employees in determining outcomes, in the form of job satisfaction (Brower et al., 2000; Dulebohn et al., 2012). Empathy has been and will always be an important tool for human life and human cooperation (Axelrod, 2009; Bowles \& Gintis, 2011; Dunbar et al., 2005), and in an office setting it has allowed leaders to send signals to the employees under them that they can be trusted, and at the same time create positive feelings and personal emotional connections (Madlock, 2008; Mayfield \& Mayfield, 2015). An empathetic leader who shows trust in his/her employees is important to the millennial generation, as they consider that this kind of leadership style matches their need for cooperation in the workplace (Bowles \& Gintis, 2011). Having their leader's trust satisfies the well-being of millennial employees (job satisfaction). The support, encouragement, and praise given by the leader are signals that their working environment values people, which is important for many millennials (Hughes, 2015). This study is one of many justifications supporting the notion that this relationshiporiented leadership style could maximize employees' job satisfaction for a generation that in general is more emotional and peopleoriented, as opposed to the mechanical 9 to 5 traditional office culture that the previous generations are accustomed to (Hughes, 2015).

In regard to Hypothesis 2, it is stated that empathetic leadership is negatively related to the intention to leave; the result of this study also confirmed that relationship. The intention to leave commonly increases when employees 
experience emotional exhaustion (Blomme et al., 2010), higher pressure and demands that work needs to be done quickly, a lack of energy and time to do all the work, and tasks or work that had to be done at the same time, especially in dynamic start-up companies. At the same time, millennials tend to be mentally more sensitive and emotional (Mind Share Partners' Mental Health at Work 2019 Report, 2019). However, having a leader who uses motivational language when expressing an emotional relationship, understands the millennials' work situation, and supports them in handling their problems causes millennials to feel less emotionally exhausted (Maslach \& Leiter, 2016), and with less intention to leave the organization. As Kock et al., (2018) stated, empathetic leadership not only puts an emphasis on understanding the emotional state of the followers, but is also willing to take care of them, making the followers feel that their leader recognizes and understands their feelings. Such a leadership style provides motivation, support, direction, and feedback that make them much less likely to leave the organization. Looking in more detail at the items of empathetic leadership, it is hard to believe that someone would leave an organization if their leader gives them praise, encouragement, support, and has trust in their professional development.

The result of the analysis shows that Hypothesis 3 is supported, and its mediation effect is partial. Hypothesis 3 argues that needs' satisfaction mediates the relationship between empathetic leadership and job satisfaction. The result corresponds to the research that argues that empathy in the office is a significant part of a leader's role when giving support to his or her subordinates (Cornelis et al., 2013), since when leaders are emotionally supportive, the interaction between the two could result in the employees feeling connected to, supported by, and cared for by their leader, and that increases their job satisfaction, while a lack of support could worsen the phenomenon (Bono et al., 2007; Chiesa \& Serretti, 2011). Additionally, in the case of a partial mediation effect, it suggests that empathetic leadership, as an independent variable, remains significant even when the mediating variable of needs' satisfaction is introduced. This shows that the job satisfaction of employees is influenced not only by their need for satisfaction but it may also be increased due to the empathetic leadership of their leaders, regardless of their needs' satisfaction, which is reasonable when we see that the need for satisfaction is a very broad subject, and it does not only cover office related matters but also one's psychological need for satisfaction inside and outside the office. This result supports the self-determination theory (Ryan \& Deci, 2002 and Ryan et al., 1996) which stated that needs are the nutriments that are essential for individuals to survive and grow.

With regard to Hypothesis 4, it is written that needs' satisfaction mediates the negative effect of empathetic leadership on the employees' intention to leave. The result showed that there is a partial mediation of that relationship. The mediating process operates as follows: First, empathetic leadership affects the need for satisfaction. Highly empathetic leaders lead to a high need for satisfaction, and then that need generates a stronger perception about not leaving the organization among the millennials. As they are the generation known as the "job hopping generation" (Gallup, 2016), changing jobs for millennials is not a big deal. However, this study found that needs' satisfaction mediates the relationship of empathetic leadership and the intention to leave. The existence of a leader who is emotionally supportive of millennials improves the interaction between the two, and reduces their intention to leave. This generation 
is also known for their knowledge and skills regarding technology (they are technologically savvy) (PWC, 2011), and in the current dynamic environment, such capabilities are an important asset when looking for another job. But, given the result of the study, it is speculated that the millennials may sacrifice the intention of looking for a new job since their needs' satisfaction is already fulfilled by their current workplace's leaders, who are empathetic.

\section{CONCLUSIONS}

Needs' satisfaction in the office setting consists of autonomy, competence, and relatedness (Deci et al., 2001). From this study, we can see that there is a significant positive relationship between empathetic leadership and needs' satisfaction, when a leader treats his or her employees with empathy, it satisfies the employees psychological needs, but it is important to note that empathetic leadership might have a stronger effect on the relatedness part of an employee's job satisfaction than it has for the sections of autonomy and competence. Having written in the correlation and confirmatory factor analysis that some of the items for needs' satisfaction fail to fulfill the threshold, this study notes that the remaining items belong to the relatedness dimension of needs' satisfaction. Statements that were meant to study points of relatedness, for example "I really like the people I interact with" and "I get along with people I come into contact with" focus on interpersonal relationships. Therefore, it is important to stress that the need for satisfaction is indeed very broad and the result of the validity testing might be explained by the notion that the mediating role of needs' satisfaction in this model is multidimensional and not unidimensional, and the relatedness dimension has the most important mediating role between empathetic leadership and job satisfaction.
Following Blau's (1964) writings on social and economic exchanges, the leader-member exchange theory assumes that leaders and followers are involved in an exchange relationship. Followers follow because they receive something from the leader. In return, the leader gets something from his followers (Messick, 2005). In the context of the workplace, followers expect to get agreeable leadership, have their feelings and emotions understood, be provided with emotional support and helped with their self-development, and in return, leaders expect their followers to help achieve the organizational goals, which in this research is through greater job satisfaction and less desire to leave. Hence, the quality of the exchange relationship is the basic unit of analysis between leaders and followers (Van Breukelen et al., 2006). Rahn et al., (2016) in this regard offered the congruence between the employees and employers that influences the quality. The quality shown here is manifested in terms of having a good relationship, for example the leaders showing admiration, encouragement, support and trust in their followers. For millennials, this kind of emotional support matches their characteristics, and they behave accordingly. Consequently, to increase the wellbeing of millennials, leading them empathetically is strongly suggested.

Regarding the intention to leave, it has been and will be an important issue for organizations. When an employee leaves, the resources invested in that employee through training, development, and education are lost. The effect of a high employee turnover, with the loss of "good" employees and a large increase in recruitment and retraining costs (Mchugh \& Brennan, 1992), cannot be underestimated. Turnover also creates serious consequences for the remaining employees, as a high turnover may have a negative effect on the morale of the 
remaining employees. Thus, organizations need to find a solution to reduce their employees' intention to leave. High turnover usually indicates employee dissatisfaction, caused by several factors. They may be underpaid, undervalued, or not challenged enough, or see limited opportunities to develop, or have poor relations with their co-workers or supervisors (Ertas, 2015). Whatever the reason, the turnover intention is not desired by management, and empathetic leadership can be a solution.

There is an ongoing debate about whether a leadership style can be born or made. For example, citing many famous people such as Mahatma Gandhi, George Washington, Abraham Lincoln, Nelson Mandela and Dr. Martin Luther King, the "great man" theory emerged (Di Gulio, 2014), which believed that leaders were born; it states that a leader is somehow naturally skilled, and those skills appear as a product of the society they lived in, which would not have been possible if the current social conditions had existed then. However, the development of the study of leadership theories indicates that the majority of what it takes to be a good leader is not inherited. The nurturing approach to leadership, as opposed to the natural approach, can be seen in the evolution of leadership theories such as transactional leadership, transformational leadership, ethical leadership (Karim et al., 2019), visionary leadership, and strategic leadership, among many others. This research believes that, borrowing the idea of the intervention program of respect (Lee Smith \& Kelloway, 2016), and talent climate (King, 2017), leaders can be made but disciplined efforts have to be invested in their creation. The recent work of Avolio and Hannah, (2019) clearly highlighted the systematic and exhaustive process of developing a leader. Management is urged to follow that process if empathetic leadership is to prevail; especially for managing a millennial workforce, which the majority of the world's workforce will be in the coming decades.

Since the study was conducted during the COVID-19 pandemic period, some of the result of the research may be influenced by those circumstances. During that pandemic, many companies rationalized their workforces, which meant involuntarily turnover happened. As such, it was assumed that many millennials reduced their tendency to look for another job, as survival was probably more important than following their career path by looking for challenging and promising jobs. This study suggests conducting the study again under normal circumstances, in order to get results that can be analyzed and compared to this study conducted in an unusual environment. Second, the study limits its generalizability since it assumed there was only one type of start-up. In fact, there are many types of start-ups. Thus, broadening the context of the study by researching other types of start-up firms would contribute to the generalization of the findings

\section{REFERENCES}

Ajzen, I. (1991). The theory of planned behavior. Organizational Behavior and Human Decision Processes, 50(2), 179$211 . \quad$ https://doi.org/10.1016/07495978(91)90020-T

Ali, N. (2009). Factors Affecting Overall Job Satisfaction and Turnover Intention. Journal of Management Science, 2: 239-252.

Avolio, B. J., \& Hannah, S. T. (2019). An enduring leadership myth. Organizational Dynamics, 100730. https://doi.org/10.1016/ j.orgdyn.2019.08.002

Axelrod, R. (2009). The evolution of cooperation (Revision). Basic Book.

Barclay, D., Higgins, C., \& Thompson, R. (1995). The Partial Least Squares (PLS) 
Approach to Causal Modeling: Personal Computer Adoption and Use as an Illustration. Technology Studies, 2(2), 285324.

Bass, B. M. (1990). From transactional to transformational leadership: Learning to share the vision. Organizational Dynamics, (Winter): 19-31.

Baumeister, R. F., \& Leary, M. R. (1995). The need to belong: Desire for interpersonal attachments as a fundamental human motivation. In Psychological Bulletin (Vol. 117, Issue 3, pp. 497-529). American Psychological Association.

https://doi.org/10.1037/0033-

2909.117.3.497

Bennis, W. (2007). The challenges of leadership in the modern world: Introduction to the special Issue. American Psychologist, 62(1), 2-5. https://doi.org/10.1037/0003066X.62.1.2

Blomme, R. J., Van Rheede, A., \& Tromp, D. M. (2010). Work-Family Conflict as a Cause for Turnover Intentions in the Hospitality Industry. Tourism and Hospitality Research, 10(4), 269-285. https://doi.org/10.1057/thr.2010.15

Bolland, E., \& Lopes, C. (2014). Generations and Works. Palgrave MacMillan.

Bono, J. E., Foldes, H. J., Vinson, G., \& Muros, J. P. (2007). Workplace Emotions: The Role of Supervision and Leadership. Journal of Applied Psychology, 92(5), 1357-1367. https://doi.org/10.1037/00219010.92.5.1357

Bowles, S., \& Gintis, H. (2011). A cooperative species: Human reciprocity and its evolution. Princeton University Press.

Brower, H. H., Schoorman, F. D., \& Tan, H. H. (2000). A model of relational leadership: The integration of trust and leader-member exchange. The Leadership Quarterly, 11(2), 227-250. https://doi.org/10.1016/S10489843(00)00040-0

Cammann, C., Fichman, M., Jenkins, G. D., \& Klesh, J. (1983). Michigan Organizational
Assessment Questionnaire. In S. E. Seashore, E. E. Lawler, P. H. Mirvis, \& C. Cammann (Eds.), Assessing Organizational Change: A Guide to Methods, Measures, and Practices (pp. 71-138). WileyInterscience.

Cardador, M. T., Dane, E., \& Pratt, M. G. (2011). Linking calling orientations to organizational attachment via organizational instrumentality. Journal of Vocational Behavior, 79(2), 367-378.

https://doi.org/10.1016/j.jvb.2011.03.009

Chou, S. Y. (2012) Millennials in the Workplace: A Conceptual Analysis of Millennials' Leadership and Followership Styles. International Journal of Human Resource Studies, May 2(2) DOI: 10.5296/ijhrs.v2i2.1568

Chiesa, A., \& Serretti, A. (2011). Mindfulness based cognitive therapy for psychiatric disorders: A systematic review and metaanalysis. Psychiatry Research, 187(3), 441453.

https://doi.org/10.1016/j.psychres.2010.08.0 11

Chopra-McGowan, A. (2019). What Startup Employees Can Teach the Rest of Us About Work. https://hbr.org/2019/06/what-startupemployees-can-teach-the-rest-of-us-aboutwork

Cornelis, I., Van Hiel, A., De Cremer, D., \& Mayer, D. M. (2013). When leaders choose to be fair: Follower belongingness needs and leader empathy influences leaders' adherence to procedural fairness rules. Journal of Experimental Social Psychology, 49(4), 605-613. https://doi.org/10.1016/j.jesp.2013.02.016

Deci, E. L., Ryan, R. M., Gagné, M., Leone, D. R., Usunov, J., \& Kornazheva, B. P. (2001). Need satisfaction, motivation, and wellbeing in the work organizations of a former eastern bloc country: A cross-cultural study of self-determination. Personality and Social Psychology Bulletin, 27(8), 930-942. https://doi.org/10.1177/0146167201278002

Di Gulio, J. V. (2014). Are leaders born or 
made? PSM310 Leadership and Business Acumen.

https://www.researchgate.net/publication/27 0684591_Are_leaders_born_or_made

Dulebohn, J. H., Bommer, W. H., Liden, R. C., Brouer, R. L., \& Ferris, G. R. (2012). A Meta-Analysis of Antecedents and Consequences of Leader-Member Exchange: Integrating the Past With an Eye Toward the Future. Journal of Management, 38(6), 1715-1759.

https://doi.org/10.1177/0149206311415280

Dunbar, R., Barrett, L., \& Lycett, J. (2005). Evolutionary psychology: A beginner's guide (Oneworld).

Edmondson, A. C., \& Lei, Z. (2014). Psychological Safety: The History, Renaissance, and Future of an Interpersonal Construct. Annual Review of Organizational Psychology and Organizational Behavior, 1(1), 23-43.

https://doi.org/10.1146/annurev-orgpsych031413-091305

Ertas, N. (2015). Turnover Intentions and Work Motivations of Millennial Employees in Federal Service. Public Personnel Management, 44(3), 401-423. https://doi.org/10.1177/0091026015588193

Ferri-Reed, J. (2014). Are Millennials Employees Changing How Managers Manage? The Journal for Quality and Participation, 37(2), 15-35.

Firth, L., Mellor, D. J., Moore, K. A., \& Loquet, C. (2004). How can managers reduce employee intention to quit? Journal of Managerial Psychology, 19(2), 170-187. https://doi.org/10.1108/0268394041052612 7

Fornell, C., \& Larcker, D. F. (1981). Evaluating structural equation models with unobservable variables and measurement error. Journal of Marketing Research, 18(1), 39-50. https://doi.org/10.2307/3151312

Gallup. (2016). How Millennials Want to Work and Live Purpose. Gallup.Inc, 23. www.gallup.com/contact
Geertshuis, S. A., Morrison, R. L., \& CooperThomas, H. D. (2015). It's not what you say, it's the way that you say it: The mediating effect of upward influencing communications on the relationship between leader-member exchange and performance ratings. International Journal of Business Communication, 52(2), 228-245. https://doi.org/10.1177/2329488415572784

Gilet, A. L., Mella, N., Studer, J., Griihn, D., \& Labouvie-Vief, G. (2013). Assessing dispositional empathy in Adults: A french validation of the interpersonal reactivity index (IRI). Canadian Journal of Behavioural Science, 45(1), 42-48. https://doi.org/10.1037/a0030425

Gilmer, B. (1974). Industrial Psychology. McGraw Hill Book Company.

Hair, J. F., Anderson, R. E., Tatham, R. L., \& Black, W. C. (1998). Multivariate Data Analysis (5th ed.). Prentice-Hall International, Inc.

Hanson-Rasmussen, N. J., \& Lauver, K. J. (2018). Environmental responsibility: millennial values and cultural dimensions. Journal of Global Responsibility, 9(1), 6$20 . \quad$ https://doi.org/10.1108/jgr-06-20170039

Hughes, D. (2015). Will millennials ruin the workplace? Statesman Journal. https://www.statesmanjournal.com/story/opi nion/columnists/dickhughes/2015/11/14/millennials-ruinworkplace/75767920/

Hulland, J. (1999). Use of Partial Least Squares (PLS) in Strategic Management Research: A Review of Four Recent Studies. Strategic Management Journal, 20(2), 195-204.

Ilies, R., Arvey, R. D., \& Bouchard, T. J. (2006). Darwinism, behavioral genetics, and organizational behavior: A review and agenda for future research. Journal of Organizational Behavior, 27(2), 121-141. https://doi.org/10.1002/job.351

Kaifi, B. A., Nafei, W. A., Khanfar, N. M., \& Kaifi, M. M. (2012). A multi-generational 
workforce:

managing and understanding millennials. International Journal of Business \& Management, 7(24), 88-93

Karim, A., Mardhotillah, N. F., \& Samadi, M. I. (2019). Ethical leadership transforms into ethnic: Exploring new leaders's style of Indonesia. Journal of Leadership in Organizations, 1(2), 146-157.

https://doi.org/https://doi.org/10.22146/jlo.4 4625

Kelloway, E. K., Gottlieb, B. H., \& Barham, L. (1999). The source, nature, and direction of work and family conflict: A longitudinal investigation. In Journal of Occupational Health Psychology (Vol. 4, Issue 4, pp. 337-346). https://doi.org/10.1037/10768998.4.4.337

King, K. A. (2017). The talent climate: Creating an organisational context supportive of sustainable talent development through implementation of a strong talent system. Journal of Organizational Effectiveness, 4(4), 298-314.

https://doi.org/10.1108/JOEPP-03-20170023

Kock, N., Mayfield, M., Mayfield, J. R., Sexton, S., \& De La Garza, L. M. (2018). Empathetic Leadership: How Leader Emotional Support and Understanding Influences Follower Performance. Journal of Leadership and Organizational Studies, 26(2), 217-236.

https://doi.org/10.1177/1548051818806290

Landrum, S. (2018). Millennials Are Happiest When They Feel Connected to Their CoWorkersle.

https://www.forbes.com/sites/sarahlandrum/ 2018/01/19/millennials-are-happiest-whenthey-feel-connected-to-their-coworkers/\#6886e8d3a2fd

Lee Smith, S., \& Kelloway, E. K. (2016). Respect in the workplace: an evaluation of a short online intervention program. Journal of Organizational Effectiveness, 3(4), 395410. https://doi.org/10.1108/JOEPP-022016-0008
Lloyd, K. J., Boer, D., \& Voelpel, S. C. (2015). From listening to leading: Toward an understanding of supervisor listening within the framework of leader-member exchange theory. International Journal of Business Communication, 54(4), 431-451. https://doi.org/10.1177/2329488415572778

Locke, E. A. (1976). The Nature and Causes of Job Satisfaction. In M. D. Dunnette (Ed.), Handbook of Industrial and Organizational Psychology (pp. 1297-1343).

Long, C. S., \& Thean, L. Y. (2011). Relationship between Leadership Style, job Satisfaction and Employee's Turnover: A Literature Review. ResearchJournal of Business Management, 5 (3): 91-100.

Madlock, P. E. (2008). The Link Between Leadership Style, Communicator Competence, and Employee Satisfaction. The Journal of Business Communication (1973), 45(1), 61-78. https://doi.org/10.1177/0021943607309351

Mahan, T., Nelms, D., Bearden, C., \& Pearce, B. (2019). Retention report. https://info.workinstitute.com/hubfs/2019 Retention Report/Work Institute 2019 Retention Report final-1.pdf

Martin, G. (2005). Managing People in Changing Contexts. Edinburgh Business School.

https://www.ebsglobal.net/EBS/media/EBS/ PDFs/Managing-People-ChangingContexts-Course-Taster.pdf

Maslach, C., \& Leiter, M. P. (2016). Burnout. Encyclopedia of Mental Health: Second Edition, 222-227. https://doi.org/10.1016/B978-0-12-3970459.00149-X

Mayfield, M., \& Mayfield, J. (2015). The effects of leader motivating language use on employee decision making. International Journal of Business Communication, 53(4), 465-484. https://doi.org/10.1177/2329488415572787

Mchugh, M., \& Brennan, S. (1992). Organization Development and Total Stress 
Management. Leadership \& Organization Development Journal, 13(1), 17-32.

McClelland, D.C., \& Burnham, D. H. (1976). Power is the Great Motivator. Harvard Business Review, 54, 100-110

Messick, D. M. (2005). On the Psychological Exchange Between Leaders and Followers. In D. M. Messick \& R. M. Kramer (Eds.), The Psychology of Leadership (pp. 83-98). Lawrence Erlbaum Associates.

Millennials in the workplace. (2017). ELI Learning Solutions.

https://www.eliinc.com/everything-needknow-millennials-workplace-infographic/

Mind Share Partners' Mental Health at Work 2019 Report. (2019). Mind Share Partners. https://www.mindsharepartners.org/downloa d-2019report

Murphy, M. (2018). The Top Thing That Millennials Want From You Is Absolutely Free.

https://www.forbes.com/sites/markmurphy/ 2018/11/11/the-top-thing-that-millennialswant-from-you-is-absolutelyfree/\#79523bc6c352

Negoro, M. C. W. (2020). The Effect of Empathetic Leadership to Employee Job Satisfaction and the Mediating Role of Employee Need Satisfaction: A Study of Indonesian Millennials in the Start-up Industry. Bachelor Thesis, Universitas Gadjah Mada.

Owens, B. P., \& Hekman, D. R. (2016). How does leader humility influence team performance? Exploring the mechanisms of contagion and collective promotion focus. Academy of Management Journal, 59(3), 1088-1111.

https://doi.org/10.5465/amj.2013.0660.

Purnomo, H., Karim, A., Rahmatullah, A. S., \& Sudrajat, S. (2020). Principals' personality, leadership, teachers' job satisfaction and students' achievement. International Journal of Psychosocial Rehabilitation, 24(08), 4581-4596.

https://doi.org/10.37200/IJPR/V24I8/PR280
475.

PWC. (2011). Millennials at work: Reshaping the workplace. Pricewaterhouse Coopers International Limited (PwCIL), 1-28.

Qodriah, S. L., Hartati, W., \& Karim, A. (2019). Self-leadership and career success: Motivation of college lecturers. Journal of Leadership in Organizations, 1(2), 79-95.

Rahn, D. L., Jawahar, I. M., Scrimpshire, A. J., \& Stone, T. (2016). Are leaders defined by followers? Role of follower's ILT and the mediating influence of LMX on follower outcomes. Journal of Organizational Effectiveness, 3(1), 43-69.

https://doi.org/10.1108/JOEPP-04-20150016

Reb, J., Narayanan, J., \& Chaturvedi, S. (2012). Leading Mindfully: Two Studies on the Influence of Supervisor Trait Mindfulness on Employee Well-Being and Performance. Mindfulness, 5(1), 36-45. https://doi.org/10.1007/s12671-012-0144-z

Ryan, R. M., \& Deci, E. L. (2000). Selfdetermination theory. Development of SelfDetermination Through the Life-Course, 55(1), 47-54. https://doi.org/10.1007/97894-024-1042-6_4

Ryan, R. M., \& Deci, E. L. (2002). Overview of self-determination theory: An organismicdialectical perspective. In Handbook of selfdetermination research. (pp. 3-33). University of Rochester Press.

Ryan, R. M., Sheldon, K. M., Kasser, T., \& Deci, E. L. (1996). All Goals Were Not Created Equal: An Organizational Perspective on the Nature of Goals and Their Regulation, in P.M. Gollwitzer \& J. A. Bargh (eds), The Psychology of Action: Linking Motivational and Cognition to Behavior (pp. 7-26). New York, NY: Goilford

Smith, T.J. and Nichols, T. (2015). Understanding the Millennial Generation. Journal of Business Diversity, Vol. 15(1)

Stevenson, A. (Ed.). (2010). Oxford Dictionary of English (Third). Oxford University Press. 
Utomo, W. P. (2019). Indonesia Millennial Report 2019. IDN Research Institute, 01, 61.

https://www.idntimes.com/indonesiamillenn ialreport2019

Van Breukelen, W., Schyns, B., \& le Blanc, P. (2006). Leader-Member Exchange Theory and Research: Accomplishments and Future Challenges. Leadership, 2(3), 295-316. https://doi.org/10.1177/1742715006066023

Williams, R. (2017). The New Startup Attire: Just Be You.

https://www.forbes.com/sites/rodneywilliam s/2017/03/30/the-new-startup-attire-just-beyou/\#22e6f96c64b2

Wong, M., Gardiner, E., Lang, W., \& Coulon, L. (2008). Generational differences in personality and motivation: Do they exist and what are the implications for the workplace? Journal of Managerial Psychology, 23(8), 878-890. https://doi.org/10.1108/0268394081090437 6

Zhu, Y. (2012). A review of job satisfaction. Asian Social Science, 9(1), 293-298. https://doi.org/10.5539/ass.v9n1p293. 